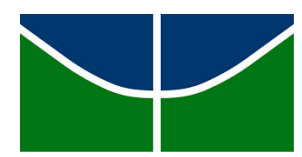

Universidade de Brasília

Instituto de Letras

Departamento de Linguística, Português e Línguas Clássicas

Iane Mariana dos Santos

\title{
Uso do clítico se mais infinitivo: para além de uma análise prescritivista
}


Iane Mariana dos Santos

\section{Uso do clítico se mais infinitivo: para além de uma análise prescritivista}

Monografia apresentada à disciplina Trabalho de Conclusão de Curso como pré-requisito parcial para a obtenção de grau de Licenciada em Letras, habilitação Língua Portuguesa e Respectiva Literatura.

Orientador: Dr. Marcus Vinícius da Silva Lunguinho.

Brasília 
A Deus, por ter me concedido o dom da vida e por ter me ajudado até aqui, dedico este trabalho. 
"Quando falamos uma língua sabemos muito mais do que aquilo que aprendemos."

Noam Chomsky 


\section{AGRADECIMENTOS}

Aos meus pais, por acreditarem no meu sonho de ingresso numa universidade pública e por subsidiarem esse sonho em constante incentivo sem medirem esforços para a concretização dele. Vocês são o meu tesouro!

Aos meus queridos irmãos, que sempre me incentivaram a dar continuidade aos meus estudos e me apoiaram muito como podiam durante esse período.

Ao meu eterno namorado pelo companheirismo desde o início da minha graduação. Obrigada por me buscar nas aulas de sexta-feira à noite, por me levar à universidade para as aulas de sábado, e pelas incansáveis idas aos domingos à biblioteca. O seu apoio foi indispensável.

A todos os professores que me acompanharam durante a minha jornada acadêmica até aqui. Vocês foram essenciais na minha formação intelectual e cidadã.

Ao meu orientador, Dr. Marcus Vinícius da Silva Lunguinho, que, desde a primeira aula de sintaxe, instigou-me a pesquisar sobre esse incrível fenômeno que é a linguagem. Você é um exemplo de professor e de pesquisador que, sem dúvidas, quero vir a ser.

Àquelas pessoas que não estão citadas aqui, mas que direta ou indiretamente contribuíram para a realização deste projeto: a minha gratidão a todos vocês. Quero, um dia, poder honrá-los. 


\section{RESUMO}

O objetivo deste trabalho é analisar o uso do clítico se mais infinitivo. Para este trabalho, foram apresentadas as perspectivas da Gramática Tradicional e da Linguística, que serão os pressupostos teóricos da pesquisa. Foi analisado um corpus de 50 dados de língua escrita formal e informal, coletados na internet, os quais servirão de base para a nossa pesquisa. A apreciação de dados consistiu na descrição dos contextos em que o se mais infinitivo ocorre e na análise de como tal clítico pode ser interpretado nesse tipo de construção. A apreciação dos dados revelou que as construções infinitivas com se, nas nossas amostras, ocorrem sempre em contextos preposicionados; funcionando o se como indeterminador e ocupando a posição de sujeito.

Palavras-chave: $\mathrm{O}$ uso do se mais infinitivo. Construções infinitivas com se no português brasileiro. 
ABSTRACT 


\section{SUMÁRIO}

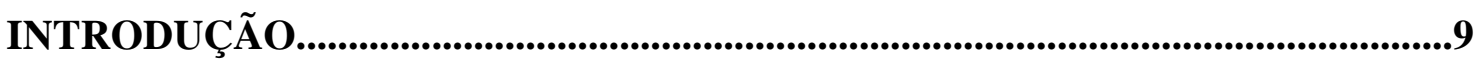

1. Sobre o infinitivo e o clítico se: a perspectiva da Gramática Tradicional.............10

1.1. Gramática Normativa da Língua Portuguesa..................................................... 10

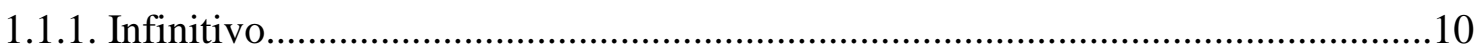

1.1.2. Se

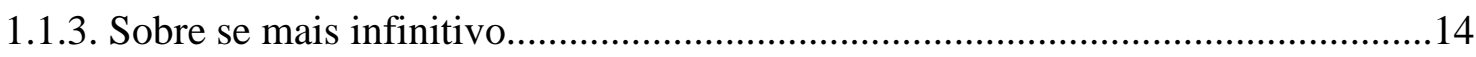

1.2. Nova Gramática do Português Contemporâneo..................................................... 14

1.2.1. Infinitivo

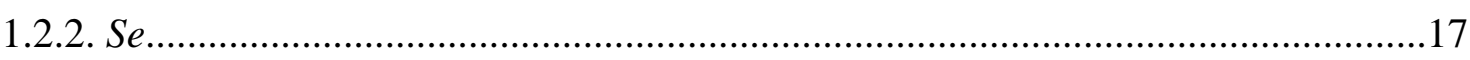

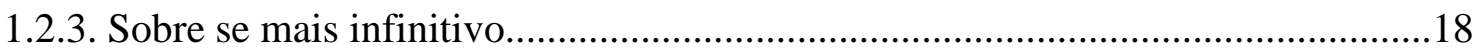

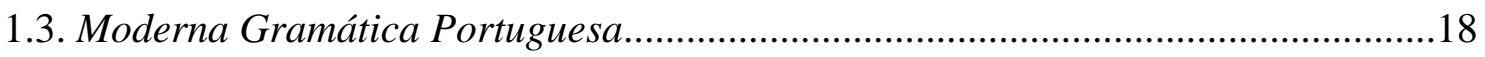

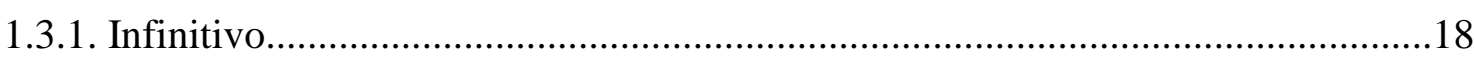

1.3.2. Se

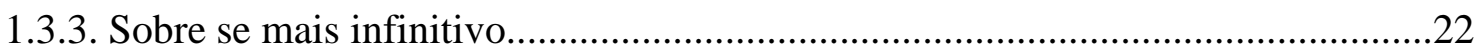

Conclusões preliminares..........................................................................................................23

2. Sobre o infinitivo e o clítico se: a perspectiva dos estudos linguísticos..................24

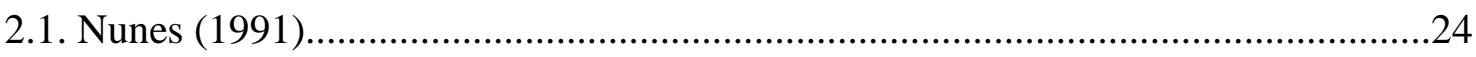

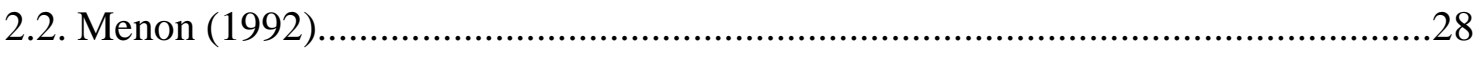

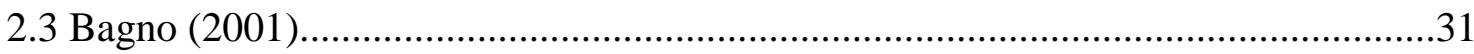

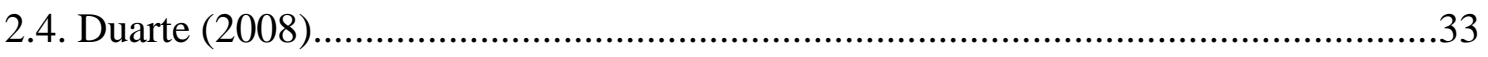

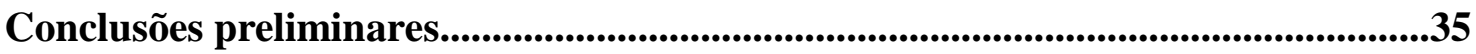

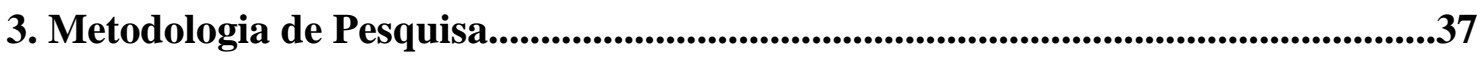

3.1. O objeto de análise e a questão da pesquisa......................................................... 
3.1.1. Descrição dos dados.

3.2. A amostra de língua escrita formal e informal: dados da internet. 37

3.2.1. Dados selecionados para a análise .38

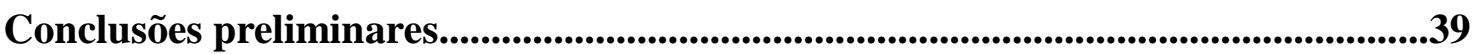

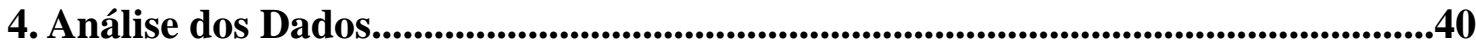

4.1.O uso do se mais infinitivo na amostra de língua escrita formal e informal.............40

Conclusões preliminares.....................................................................................................................48

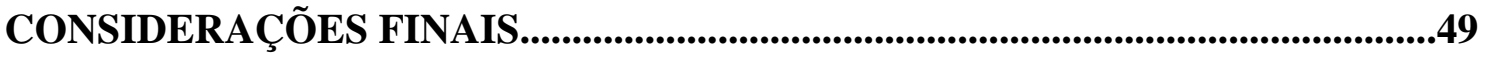

REFERÊNCIAS BIBLIOGRÁFICAS.......................................................................54 


\section{INTRODUÇÃO}

Este trabalho tem por objetivo estudar o uso do clítico se mais infinitivo, a fim de descrever em que contextos ocorre esse fenômeno e analisar como o se pode ser interpretado em tais contextos.

O trabalho será estruturado em quatro capítulos. No primeiro capítulo, serão selecionadas três gramáticas - Gramática Normativa da Língua Portuguesa, Nova Gramática do Português Contemporâneo e Moderna Gramática do Português, com o propósito de mostrar o entendimento de cada autor acerca do se e do infinitivo.

O segundo capítulo será dedicado à perspectiva linguística acerca do se e do infinitivo. Serão utilizados os trabalhos de Jairo Nunes (1991), de Odete Menon (1992), de Marcos Bagno (2001) e de Maria Eugênia Duarte (2008). Dissertaremos sobre o que foi dito por esses autores nesses trabalhos dedicados a fim de buscar um significado mais concreto para o tema em questão.

O terceiro capítulo se volta à metodologia de pesquisa, dividido em duas seções: na primeira, descreve-se o objeto de análise e a questão de pesquisa e, na segunda, apresenta-se a metodologia de coleta de dados que definirá o corpus no qual se fundamenta a pesquisa.

O quarto e último capítulo consistirá na descrição dos dados coletados e na análise desses dados.

Por fim, seguem as considerações finais, que elencam os achados da pesquisa e que responderão às questões de pesquisa, bem como os desdobramentos futuros que essa investigação pode vir a tomar. 


\title{
CAPÍTULO 1 \\ Sobre o infinitivo e o clítico se: \\ A perspectiva da Gramática Tradicional ${ }^{1}$
}

\section{Introdução}

Neste capítulo, pretende-se descrever o que três gramáticas tradicionais da língua portuguesa, a saber, Gramática Normativa da Língua Portuguesa, Nova Gramática do Português Contemporâneo e Moderna Gramática do Português, apresentam acerca: a) do emprego do infinitivo no português, e b) do uso do clítico se, atuando esse como indeterminador e como apassivador.

\subsection{Gramática Normativa da Língua Portuguesa}

\subsubsection{Infinitivo}

O capítulo 10 da Gramática Normativa da Língua Portuguesa, de Rocha Lima, trata do estudo morfológico dos verbos. O infinitivo, ao lado do particípio e do gerúndio, é apresentado, inicialmente, como sendo uma forma nominal, distinta da forma verbal propriamente dita:

\begin{abstract}
a gramática clássica as denominava formas infinitas, em contraste com as do indicativo, subjuntivo e imperativo, chamada formas finitas. Autores modernos intitularam-nas formas nominais do verbo, ou mais expressivamente, verboides. (LIMA, 2011, p. 168).
\end{abstract}

Essa distinção, segundo o autor, justifica-se pelo fato de o infinitivo e as demais formas nominais não exercerem função exclusivamente verbal e, também, por não apresentarem certas características essenciais do verbo. Nesse sentido, o infinitivo é assim definido:

\footnotetext{
${ }^{1}$ Segundo José Carlos de Azeredo (2015), a Gramática Tradicional, em sua acepção pedagógica, isto é, relacionada ao ensino da leitura e da escrita, "compreende o conteúdo a ser apreendido nas escolas básica e média como requisito para o domínio e emprego das formas corretas da linguagem falada e escrita". (AZEREDO, 2015, p. 198, grifo meu).
} 
o infinitivo é antes um substantivo: como este, pode ser sujeito ou complemento de um verbo, e, até vir precedido de artigo. (LIMA, 2011, p. 168).

Apesar de o infinitivo carecer, normalmente, de flexão, segundo o autor, há, no português, a possibilidade e, ao mesmo tempo, a particularidade em relação a outras línguas, de o infinitivo poder se flexionar em número e em pessoa e, consequentemente, de se referir a um sujeito. Vejamos isso nos exemplos a seguir.

(1) Fumar é nocivo à saúde. ${ }^{2}$

(2) a. Trabalha, meu filho, para agradar a Deus.

(3) b. Trabalha, meu filho, para agradares a Deus.

No exemplo (1), há o infinitivo impessoal, o qual não tem nem sujeito, nem possui flexão; e, nos exemplos em (2), há o infinitivo pessoal, que se refere a um sujeito, podendo se flexionar, como em (2a), ou não, como em (2b).

A partir dessas considerações, o autor elenca regras para o emprego do infinitivo, tendo como referência a classificação mencionada acima:

\section{Infinitivo não flexionado}

a) Quando figura indeterminadamente, na plenitude do seu valor nominal, sem referirse a nenhum sujeito:

(3) Viver é lutar.

b) Quando tem sentido de imperativo:

(4) Cessar o fogo, paulistas.

c) Quando, regido da preposição de, tem sentido passivo e se emprega como complemento de um adjetivo:

(5) Versos! São bons de ler, mais nada; eu penso assim.

d) Quando, precedido da preposição $a$, equivale a um gerúndio que, em locução com um verbo auxiliar, indique modo ou fim:

\footnotetext{
2 Todos os exemplos apresentados nesta seção foram extraídos da Gramática Normativa da Língua Portuguesa, páginas 503-507.
} 
(6) Todos no mesmo navio, todos na mesma tempestade, todos no mesmo perigo, e uns a cantar, outros a zombar, outros a orar e chorar?

e) Quando se agrega, como verbo principal, a um auxiliar ${ }^{3}$, formando com ele uma unidade semântica:

f) Quando seu sujeito é um pronome pessoal átono, que serve concomitantemente de complemento a um dos cinco verbos - ver, ouvir, deixar, fazer e mandar:

(7) Viu-os partir um herege.

\section{Infinitivo flexionado}

Emprega-se obrigatoriamente num só caso - quando tem sujeito próprio, distinto do sujeito da oração principal - ressalvado, é claro, o item f. do caso anterior:

(8) Vivi o melhor que pude, sem me faltarem amigas.

\section{Dupla construção}

a) Quando, apesar de subordinado a um auxiliar com o qual forme um todo semântico, estiver esse auxiliar afastado do infinitivo:

(9) Todas aquelas cenas dispersas e incompletas na memória de Cervantes deviam, animadas por uma grande fantasia de poeta, sublevarem-se lhe na mente.

b) Quando o sujeito do infinitivo é um substantivo que serve ao mesmo tempo de complemento a um dos cinco verbos: ver, ouvir, deixar fazer e mandar.

b1) Com a forma não flexionada:

(10) O vento tépido, úmido e violento, fazia ramalhar as árvores do jardim.

b2) Com a forma flexionada:

(11) Viu saírem e entrarem mulheres.

\footnotetext{
${ }^{3}$ Segundo o autor, esses verbos auxiliares podem ser classificados, ainda, em modais (poder, saber, querer, dever) e acurativos (ir, principar a, começar a, costumar, acabar de, cessar de, tonar a). Sobre essa subclasse de verbos, citando Said Ali, o autor diz que o sujeito da oração será indicado pela desinência desses auxiliares, e que o verbo principal será uma forma nominal, desprovida de sujeito.
} 
c) Quando, apesar de possuir sujeito igual ao da oração principal, houver o "intuito ou necessidade de pormos em evidência o agente da ação":

(12) Virtude, sem trabalhares e padeceres, não verás tu jamais com teus olhos. (LIMA, 2011, p. 503-507)

Apesar de prescrever tais regras, o autor ressalta que ainda não há regras fixas quanto ao uso de um infinitivo em detrimento de outro. Mas que, por outro lado, os escritores infringem algumas regras, pois questões relativas à estilística (clareza, ênfase e harmonia de expressão), muitas vezes, influenciam e se sobrepõem às de ordem gramatical.

\subsubsection{Se}

Em relação ao uso do se como recurso de indeterminação do sujeito, o autor apresenta em “Termos Básicos da Oração” (capítulo 17), os seguintes exemplos:

(14) Vive-se bem aqui.

(15) Precisa-se de professores.

Nas sentenças acima, os verbos foram empregados na $3^{\text {a }}$ pessoa do singular intransitivo em (14), e trazendo complemento preposicional em (15), acompanhados do se indeterminador.

No capítulo 27, o se é apresentado, mais uma vez, mas em outra função: a de elemento apassivador, a partir dos seguintes exemplos:

(16) Alugam-se casas.

(17) Venderam-se todos os bilhetes.

As sentenças 16 e 17 estão empregadas na voz passiva, pois o sujeito é o paciente do processo verbal. Essa construção de voz passiva com o se, segundo o autor, merece uma atenção especial:

atenção especial deve merecer a concordância do verbo acompanhado da partícula "se" e seguido de substantivo no plural (...) Este substantivo, representado (geralmente) por ser inanimado, é o sujeito da frase -, razão pela qual com ele há de concordar o verbo. A índole da língua portuguesa inclina para a posposição desse sujeito ao verbo; aponta-se por menos 
comum a sua presença antes do verbo, assim como vir ele representado por ser animado. (LIMA, 2011, p. 475).

Assim, na voz passiva com o se, o verbo deverá sempre concordar com o sujeito a que se refere, como em 16 - "venderam" e "casas"; e em 17 - "venderam" e "todos os bilhetes", respectivamente.

\subsubsection{Sobre se mais infinitivo}

A Gramática Normativa da Língua Portuguesa não apresenta um estudo específico voltado para o emprego do infinitivo concomitante ao uso do clítico se.

\subsection{Nova Gramática do Português Contemporâneo}

\subsubsection{Infinitivo}

A Nova Gramática do Português Contemporâneo, de Cunha \& Cintra, apresenta, no capítulo 13, no que se refere à sintaxe dos modos e dos tempos verbais, o estudo do emprego das formas nominais. Ao apresentar as formas nominais do verbo (infinito, gerúndio, particípio), os autores apontam que tais formas "caracterizam-se por não exprimirem por si nem o tempo nem o modo. O seu valor temporal e modal está sempre em dependência do contexto em que aparecem" (CUNHA \& CINTRA, 2013, p. 496). Quanto ao infinitivo, especificadamente, os autores afirmam que essa forma "apresenta o processo verbal em potência; exprime a ideia de ação, aproximando-se, assim, do substantivo". (CUNHA \& CINTRA, 2013, p. 496)

Os autores, ainda, ressaltam duas características estruturais do infinitivo:

a) O infinitivo possui, ao lado da forma simples, uma forma composta, que exprime a ação concluída; apresenta, pois, internamente, uma oposição de aspecto ${ }^{4}$ :

\begin{tabular}{|l|c|c|}
\cline { 2 - 3 } \multicolumn{1}{c|}{} & \multicolumn{2}{c|}{ Infinitivo } \\
\hline Ler & Ter lido \\
\hline
\end{tabular}

\footnotetext{
${ }^{4}$ Essa característica não é exclusiva do infinitivo. Segundo os autores, o gerúndio também apresenta uma forma composta dotadora de aspecto concluído.
} 


\begin{tabular}{|c|c|c|}
\hline Morfologia & Forma simples & Forma composta \\
\hline Semântica & Aspecto não-concluído & Aspecto concluído \\
\hline
\end{tabular}

b) O infinitivo assume, em português, duas formas: uma não flexionada; outra flexionada, como qualquer forma pessoal do verbo. (CUNHA \& CINTRA, 2013, p. 498)

Essa forma não flexionada, segundo os autores, compreende o infinitivo impessoal, o qual não tem sujeito, "porque não se refere a uma pessoa gramatical" (CUNHA \& CINTRA, 2013, p. 498). O infinitivo pessoal, por outro lado, possui sujeito próprio, podendo ou não se flexionar.

Embora estabelecidas tais diferenças morfossintáticas e, consequentemente, suas classificações, os autores afirmam que as regras gramaticais não têm sido suficientes para estabelecer critérios de emprego distintivo, uma vez que há a possibilidade de uso das duas formas do infinitivo:

\begin{abstract}
é uma das questões mais controvertidas da sintaxe portuguesa. Numerosas têm sido as regras propostas pelos gramáticos para orientar com precisão o uso seletivo das duas formas. Quase todas, porém, submetidas a um exame mais acurado, revelaram-se insuficientes ou irreais. Em verdade, os escritores das diversas fases da língua portuguesa nunca se pautaram, no caso, por exclusivas razões de lógica gramatical, mas se viram sempre, no ato da escolha, influenciados por ponderáveis motivos de ordem estilística, tais como o ritmo da frase, a ênfase do enunciado, a clareza da expressão. Por isso, parecenos mais acertado falar não de regras, mas de tendências que se observam no emprego de uma e de outra forma do infinitivo. (CUNHA \& CINTRA, 2013, p. 498).
\end{abstract}

Diante dessas considerações, os autores ressaltam que não se deve falar em "regras", e sim em "tendências" quanto ao uso de uma ou de outra forma do infinitivo. As tendências apontadas pelos autores são as seguintes:

\title{
Infinitivo não flexionado:
}

a) O infinitivo conserva a forma não flexionada:

\footnotetext{
${ }^{5}$ Quadro sistematizado para fins de organização, não interferindo, de modo algum, nos exemplos apresentados pelo autor.
} 
a1) Quando é impessoal, ou seja, quando não se refere a nenhum sujeito:

(17) Viver é exprimir-se.

a2) Quando tem valor de imperativo:

(18) E Deus responde - "Marchar!"

a3) Quando, em frase nominal de acentuado caráter afetivo, tem sentido narrativo ou descritivo (infinitivo de narração):

(19) Mais dois dias. E Catarina a piorar.

a4) Quando, precedido da preposição de, serve de complemento nominal a adjetivos como fácil, possível, bom, raro e outros semelhantes:

(20) Há decisões fáceis de manter, lembranças difíceis de afastar.

a5) Quando, regido da preposição a, equivale a um gerúndio em locuções formadas com os verbos estar, andar, ficar, viver e semelhantes:

(21) Andam a montar casa.

É também normal o emprego do infinitivo não flexionado:

a6) Quando pertence a uma locução verbal e não está distanciado do seu auxiliar:

(22) Os galos começaram a cantar.

a7) Quando depende dos auxiliares causativos (deixar, mandar, fazer e sinônimos) ou sensitivos (ver, ouvir, sentir e sinônimos) e vem imediatamente depois desses verbos ou apenas separado deles por seu sujeito, expresso por um pronome oblíquo:

(23) - Deixas correr os dias como as águas do Paraíba?

\section{Infinitivo flexionado:}

b) O infinitivo assume a forma flexionada:

b1) quando tem sujeito claramente expresso:

(27) Mas o curioso é tu não perceberes que não houve nunca "ilusão" alguma. 
b2) quando se refere a um agente não expresso, que se quer dar a conhecer pela desinência verbal:

(28) - Acho melhor não fazeres questão.

b3) quando, na $3^{\circ}$ pessoa do plural, indica a indeterminação do sujeito:

(29) Ouvi dizerem que Maria Jeroma, de todas a mais impressionante, pelo ar desafrontado e pela pintura na cara, ganhara o sertão.

b4) quando se quer dar à frase maior ênfase ou harmonia:

(30) Aqueles homens gotejantes de suor, bêbados de calor, desvairados de insolação, /a quebrarem,/a espicaçarem,/a torturarem a pedra, pareciam um punhado de demônios revoltados na sua impotência contra o impassível gigante.

\section{Dupla construção:}

c) Quando entre o auxiliar e o infinitivo se insere o sujeito deste expresso por substantivo ou equivalente:

(24) Domingos mandou os homens levantaram-se.

c1) E, mais raramente, quando o sujeito é um pronome oblíquo:

(25) Ele viu-as entrarem, prostrarem-se de braços estendidos, chorando, e não se comoveu. (CUNHA \& CINTRA, 2013, p. 499-503).

Essas tendências, segundo os autores, partem de um emprego seletivo e não de uma rigidez gramatical; e, citando Said Ali $(1965)^{6}$, afirmam que tal escolha "depende de cogitarmos somente da ação ou do intuito ou necessidade de pormos em evidência o agente da ação". (CUNHA \& CINTRA, 2013, p. 504). Assim, no primeiro caso, é preferível o uso do infinitivo não flexionado; e, no segundo caso, portanto, prefere-se o uso do infinitivo flexionado.

\subsubsection{Se}

\footnotetext{
${ }^{6}$ A obra à qual os autores se referem é A gramática secundária da língua portuguesa .
} 
O uso do clítico se no que diz respeito à indeterminação do sujeito na sentença é apresentado no capítulo 7 - "Frase, Oração, Período". Nele, os autores apontam os seguintes exemplos:

(31). Ainda se vivia num mundo de certezas.

(32). Precisa-se do carvalho; não se precisa do caniço.

(33). Comia-se com a boca, com os olhos, com o nariz.

Segundo o autor, essas sentenças seguiram um dos mecanismos para indeterminar o sujeito, ou seja, quando "o verbo não se refere a uma pessoa determinada, ou por se desconhecer quem executa a ação, ou por não haver interesse no seu conhecimento". (CUNHA \& CINTRA, 2013, p. 142). Essa regra consiste em flexionar o verbo na $3^{\text {a }}$ pessoa do singular, como nos exemplos 31, 33 e 34, seguido do clítico se. Esse, portanto, estará atuando como índice de indeterminação do sujeito.

Já no capítulo 13, no estudo das vozes do verbo, são apresentados os exemplos a seguir.

(34) Não se vê [=é vista] uma rosa neste jardim.

(35) Não se veem [são vistas] rosas neste jardim.

Essas sentenças são exemplos de construções na voz passiva a partir da combinação do clítico se (funcionando esse como pronome apassivador) e do verbo na $3^{\mathrm{a}}$ pessoa verbal, no singular ou no plural, em concordância com o sujeito. Isso porque, segundo os autores, o objeto direto da voz ativa corresponde ao sujeito da voz passiva. Assim, necessariamente, os verbos que sofrem tal processo de transformação da voz verbal devem ser transitivos.

\subsubsection{Sobre se mais infinitivo}

A Nova Gramática do Português Contemporâneo não apresenta um estudo específico voltado para o emprego do infinitivo concomitante ao uso do clítico se.

\subsection{Moderna Gramática Portuguesa}

\subsubsection{Infinitivo}

A Moderna Gramática Portuguesa, de Evanildo Bechara, no capítulo 2, subcapítulo 6, trata do estudo geral dos verbos. A definição das "Formas Nominais do Verbo" nesta 
gramática é semelhante às definições já vistas em Rocha Lima e em Cunha \& Cintra. Segundo o autor, essas formas são assim denominadas porque, "ao lado do seu valor verbal, podem desempenhar função de nomes". (BECHARA, 2009, p. 224). Assim, relativamente ao infinitivo, este pode ter função de substantivo. Função essa que é ilustrada abaixo:
a) Recordar é viver. ${ }^{7}$
b) A recordação é vida.

No exemplo acima, o autor contrasta as duas sentenças a fim de demonstrar que, em ambas, há um processo similar de construção sintática - o verbo "recordar", devido à sua forma nominal, tem o mesmo sentido de "recordação". Trata-se, segundo o autor, da possibilidade de o verbo, no infinitivo, de exercer a função de substantivo.

Quanto à classificação do infinitivo, há uma diferença de abordagem conceitual, se comparada às gramáticas já estudadas. $\mathrm{O}$ autor não afirma que "o infinitivo português, ao lado da forma infinita, isto é, sem manifestação explícita das pessoas do discurso, possui outra flexionada". (BECHARA, 2009, p. 224).

A seguir, os exemplos do autor:

\begin{tabular}{|c|c|}
\hline Infinitivo sem flexão & Infinitivo flexionado \\
\hline \multirow{3}{*}{ Cantar } & Cantar eu \\
& Cantares tu \\
& Cantar ele \\
Cantarmos nós \\
Catardes vós \\
\\
& Cantarem eles. \\
\hline
\end{tabular}

Sobre o emprego do infinitivo, o autor elenca as seguintes regras:

\footnotetext{
7 Todos os exemplos apresentados nesta seção foram extraídos da Gramática Normativa da Língua Portuguesa, páginas 224; 284-286.

${ }^{8}$ Quadro sistematizado para fins de organização, não interferindo, de modo algum, nos exemplos apresentados pelo autor.
} 
a) Infinitivo pertencente a uma locução verbal:

Não se flexiona normalmente o infinitivo que faz parte de uma locução verbal:

(36) "E o seu gesto era tão desgracioso, coitadinho, que todos, à exceção de Santa, puseram-se a rir".

Encontram-se exemplos que se afastam deste critério quando ocorrem os seguintes casos:

a. $\mathrm{O}$ verbo principal se acha afastado do auxiliar e se deseja avivar a pessoa a quem a ação se refere:

(37) "Possas tu, descendente maldito

De uma tribo de nobres guerreiros,

Implorando cruéis forasteiros,

Seres presa de vis Aimorés".

b. O verbo auxiliar, expresso anteriormente, cala-se depois:

(38) “Queres ser mau filho, deixares uma nódoa d'a infância na tua linhagem”.

b) Infinitivo dependente dos verbos causativos e sensitivos:

c) Com os causativos deixar, mandar, fazer (e sinônimos), a norma é aparecer o infinitivo sem flexão, qualquer que seja o seu agente:

(39) "Fazei-os parar".

Mas flexionado em:

(40) E deixou fugirem-lhe duas lágrimas pelas faces.

d) Com os sensitivos ver, ouvir, olhar, sentir (e sinônimos), o normal é empregar-se o infinitivo sem flexão, embora aqui o critério não seja tão rígido:

(41) Olhou para o céu, viu estrelas...escutou, ouviu ramalhar as árvores.

Os seguintes exemplos atestam o emprego do infinitivo flexionado:

(42) Creio que comi: senti renovarem-se-me as forças. 
e) Infinitivo fora da locução verbal:

Nesse caso, "a escolha da forma infinitiva depende de cogitarmos somente da ação ou do intuito ou necessidade de pormos em evidência o agente do verbo". (BECHARA, 2009, p. 285)

f) Infinitivo sem flexão - revela que a nossa atenção se volta com especial atenção para a ação verbal; a flexão serve para insistir na pessoa do sujeito:

(43) a. Estudamos para vencer na vida.

b. Estudamos para vencermos na vida.

Ocorre o infinitivo flexionado (...):

Sempre que o infinitivo estiver acompanhado de um nominativo sujeito, nome ou pronome (quer igual ao de outro verbo, quer diferente);

(44) Estudamos para nós vencermos na vida.

Sempre que se tornar necessário destacar o agente, e referir a ação especialmente a um sujeito, seja para evitar a confusão, seja para tornar mais claro o pensamento. O infinitivo concordará com o sujeito que temos em mente;

(45) Beijo-vos as mãos, senhor rei, por vos lembrardes ainda de um velho homem de armar que para nada presta hoje.

Quando o autor intencionalmente põe em relevo a pessoa a que o verbo se refere:

(46) É permitido aos versistas poetarem em prosa.

\subsubsection{Se}

No subcapítulo intitulado como "O pronome se na construção reflexa", além de ser analisada a reflexividade, o autor apresenta essas duas possibilidades léxicas com que a partícula se pode se manifestar - a construção do sujeito indeterminado e a voz passiva. Vejamos os seguintes exemplos.

a. O banco só se abre às dez horas. 
b. Abre-se às dez.

Em a., há um exemplo de construção da voz passiva com a partícula se, pois, "banco é um sujeito constituído por substantivo inanimado, não pode ser agente da ação verbal; por isso, a construção é interpretada como "passiva” (BECHARA, 2009, p. 177). Em b., por outro lado, "temos aqui um se na construção em que não há um substantivo, claro ou subtendido, que funcione como sujeito do conteúdo predicativo. Interpreta-se a construção como impessoal”. (BECHARA, 2009, p. 177).

Sobre o último exemplo, o autor acrescenta as seguintes considerações:

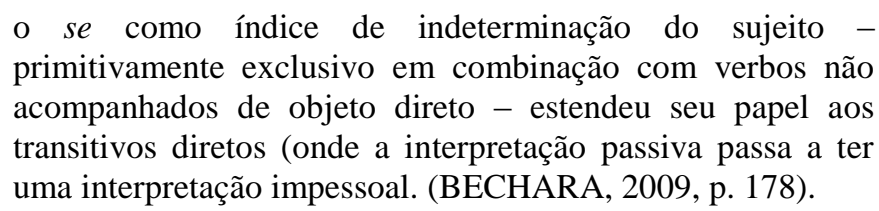

Esse contexto de mudança em relação ao clítico pode ser ilustrado a partir desses dois exemplos do autor:

(47) Vendem-se casas.

(48) Vende-se casas.

Em (47), a interpretação da sentença é a de que "casas são vendidas”, e em (48), é a de que "alguém tem casa para vender". Essa interpretação, segundo o autor, está relacionada a passagem do emprego da passiva à indeterminação do sujeito. O se como índice de indeterminação do sujeito - em regra, combinando-se com verbos não acompanhados de objeto direto -, estendeu seu papel aos transitivos diretos. Essa mudança do $s e \mathrm{AP}>s e \mathrm{IND}^{9}$ levou o falante, além de transformar a interpretação passiva em uma interpretação impessoal, a não fazer mais concordância, como no exemplo (48), pois o que era sujeito passa a ser objeto direto, função que não exige concordância com o verbo.

\subsubsection{Sobre $s e$ mais infinitivo}

A Moderna Gramática Portuguesa não apresenta um estudo específico voltado para o emprego do infinitivo concomitante ao uso do clítico se.

\footnotetext{
${ }^{9}$ Leia-se "seAP" em "se apassivador", e "seIND" em "se indeterminador".
} 


\section{Conclusões preliminares}

O infinitivo, no português, possui uma natureza nominal, isto, é, paralelo ao seu valor verbal, este pode exercer funções próprias do substantivo. Caracteriza-se, sobretudo, por não poder exprimir por si nem o tempo e nem o modo. O infinitivo, ainda, pode apresentar desinências de pessoa e de número, as mesmas desinências que caracterizam a flexão dos nomes. Essa possibilidade de poder se flexionar ou não em número e em pessoa, classifica o infinitivo em pessoal e em impessoal. O infinitivo impessoal não possui flexão e, portanto, não se refere a nenhuma pessoa gramatical (não possui sujeito), como visto no exemplo (1). O infinitivo pessoal, por outro lado, referindo-se a uma pessoa gramatical (possui sujeito), pode ou não se flexionar, como em (1a) e (1b), respetivamente.

Nas obras analisadas, é unânime que não há regras fixas quanto ao uso do infinitivo, ou seja, regras pelas quais regesse o emprego de uma forma em detrimento de outra. No entanto, os gramáticos apresentam três possibilidades de construção dessa forma nominal: o infinitivo não-flexionado, o infinitivo flexionado e a dupla construção (flexionado e nãoflexionado), apresentando casos em que se opta por uma dos dessas formas. Rocha Lima (2001) e Cunha \& Cintra (2013) ressaltam que tal escolha está relacionada muito mais à estilística; como questões relativas à clareza, à harmonia de expressão, à ênfase e ao ritmo do enunciado e etc., do que a questões de ordem gramatical.

O se é apresentado em vários usos, dentre eles como apassivador e como indeterminador. Esse contexto sintático de emprego distintivo está relacionado à transitividade verbal, ou seja, os gramáticos classificam o se de acordo com os verbos com os quais ele se combina; atribuindo às suas sentenças a voz passiva ou a indeterminação do sujeito.

Por fim, nenhuma das gramáticas analisadas traz um estudo específico voltado para o emprego do infinitivo concomitante ao uso do clítico se. 


\section{CAPÍTULO 2 \\ Sobre o infinitivo e o clítico se: \\ A perspectiva dos estudos linguísticos}

\section{Introdução}

Neste capítulo, pretende-se descrever o que a Linguística apresenta sobre o emprego do infinitivo no português e do clítico se, atuando esse como indeterminador e como apassivador. Para tanto, serão utilizados os seguintes trabalhos - Nunes (1991), Menon (1992), Bagno (2001), e Duarte (2008).

\subsection{Nunes (1991)}

$\mathrm{O}$ autor traça um percurso diacrônico em torno do se e apresenta algumas considerações sobre esse clítico relativamente a construções do português brasileiro: o surgimento do se indeterminador; a sua elisão em sentenças finitas e a sua inserção em sentenças infinitas.

Segundo o autor, há, no português europeu, uma preferência pela construção com se apassivador, e no português brasileiro, há uma preferência pelo se indeterminador. Essa "preferência" reflete-se, no português brasileiro, no surgimento do se indeterminador, “desencadeado por um processo de reanálise sintática da antiga construção com se apassivador”. (NUNES, 1991, p. 37). Citando Labov (1972), o autor acrescenta:

as construções com se apassivador devem sua sobrevivência na
modalidade escrita culta do português brasileiro à renitência da
gramática tradicional, que pauta pela norma europeia. A
concordância em construções com se no atual estágio do
português do Brasil reflete mais um fenômeno de monitoração
da escrita (que por vezes conduz a hipercorreções do tipo
tratam-se desses assuntos) que propriamente algo do domínio
do vernáculo. (LABOV, 1972, apud Nunes, 1991, p. 37 - grifo
do autor)

Trata-se, segundo Nunes (1991), de três possíveis fatores que incidiram sobre esse processo de mudança de se apassivador para se indeterminador:

a. "Reanálise do clítico: se apassivador passa do elemento identificador de estrutura do predicado (por absorver o papel temático reservado ao argumento externo) ao 
participante da relação anafórico-pronominal que se estabelece com o pronome nulo da posição de sujeito.

b. Reanálise do argumento interno: o argumento interno passa do sujeito a objeto do verbo.

c. Reanálise da categoria vazia da posição de sujeito: o expletivo que ocupa a posição de sujeito é reanalisado com um pronome nulo referencial (que é indeterminado pelo clítico se) ". (NUNES, 1991, p. 37).

Essas três hipóteses, que têm como base de análise o Princípio de Projeção ${ }^{10}$ e o Critério $\theta^{11}$ proposto por Chomsky (1981), permitem descrever e compreender o fenômeno de surgimento do se indeterminador no português brasileiro. Para ilustrar tal análise, o autor apresenta o seguinte exemplo:

(50) Comeu-se os bolos.

Em (50), há a posposição do argumento interno [os bolos]. Segundo o autor, “o crescente uso da construção com se indeterminador (de construções com discordância verbal) deve ter se dado sob influência direta da posição ocupada pelo argumento interno em estrutura-S ${ }^{12 \%}$. (NUNES, 2001, p. 39). Ou seja, a possibilidade de o argumento interno exercer a função de sujeito nessa posposição, induz ao falante a não fazer concordância. Por outro lado, o autor ressalta que o argumento interno, também, pode passar de sujeito a objeto do verbo, cujo sintagma [casas], em (51), receberia caso acusativo:

(51) Aluga-se casas.

\footnotetext{
${ }^{10}$ Cf. Novo Manual de Sintaxe, o Princípio de Projeção prevê que "as propriedades de seleção de cada núcleo lexical devem ser preservadas nos níveis de representação de DS, SS e LF, (...) procura garantir fundamentalmente que não se pode, no correr da derivação de uma sentença, aumentar ou diminuir o número de argumentos ou posições argumentais selecionadas por um dado núcleo ". (MIOTO; SILVA; LOPES, 2007, p. 141)

${ }^{11}$ Cf. Novo Manual de Sintaxe, o Critério $\theta$ prevê que "cada cadeia tem que receber um e um só papel. Cada papel tem que ser atribuído a uma e uma só cadeia”. (MIOTO; SILVA; LOPES, 2007, p. 142)

${ }_{12}$ Cf. Novo Manual de Sintaxe, Estrutura-S é um nível de representação sintática da sentença que será interpretada fonologicamente pela forma fonética. A forma fonética, por sua vez, indicará como essa estrutura é pronunciada, sendo interpretada semanticamente pela forma lógica, ou seja, o sentido da estrutura. (MIOTO; SILVA; LOPES, 2007, p. 27)
} 
As frequentes construções com se indeterminador no português brasileiro levaram a extensão do valor dos verbos transitivos aos demais verbos. Dessa maneira, qualquer verbo desde que possa ter um pronome referencial nulo na posição de sujeito (possuindo traço [+hum $]^{13}$ ) - poderia se combinar com o se indeterminador. Essa análise pode ser ilustrada pelos seguintes exemplos do autor:

(52) a. Come-se muito no inverno.

b. Trabalha-se bastante neste lugar.

c. Precisa-se de empregados.

d. É-se feliz quando se é jovem.

e. Chegou-se tarde à reunião.

f. Aqui se é visto por todos.

Nas sentenças do exemplo (52), há o emprego de vários tipos de verbos: em a, há um verbo transitivo diretos usado intransitivamente [comer]; em b, há um verbo intransitivo [trabalhar]; em c, há um verbo transitivo preposicionado; em d, há um verbo de ligação; em e, há um verbo ergativo ${ }^{14}$; e, em $\mathrm{f}$, há um verbo na voz passiva. $\mathrm{O}$ autor acrescenta ainda que:

subjaz a essa ordem a hipótese de que a expansão deve ter se dado de acordo, em primeiro lugar, com a presença de argumento externo na posição de sujeito (isso oporia os itens a, b, c e d acima ados itens e f); e em segundo lugar, com a semelhança estrutural em superfície (isso explicaria a ordem dentro dos polos. (NUNES, 1991, p. 44)

A elisão do se indeterminador, segundo o autor, está relacionada diretamente a construções de sentenças finitas. A seguir, o exemplo apresentado de Galves (1987):

(56) Nos nossos dias não usa mais saia.

Segundo Galves (1987), o exemplo (56) ilustra que o pronome nulo de terceira pessoa do singular em sentenças finitas pode gerar interpretações distintas no português brasileiro e no português europeu - neste, pode ter uma interpretação determinada, e naquele pode ter uma interpretação indeterminada. Isso porque tais construções apontam para “construções indeterminadas pela marca de concordância da terceira pessoa do plural ou

\footnotetext{
13 Traço [+humano].

14 À época, consistiria numa subclasse de verbos intransitivos que possuía argumento interno.
} 
construções com se indeterminador" (NUNES, 1991, p. 46), como nos exemplos (57) e (58), respectivamente:

(57) Nos nossos dias não usam mais saia.

(58) Nos nossos dias não se usa mais saia.

Sobre esse emprego distintivo, o autor destaca duas possíveis hipóteses de uso em relação ao português brasileiro: admite-se a concordância com paradigmas como "eles/eles fala"; e a eliminação de clíticos.

Em relação a contextos infinitivos, o autor aponta que, diferentemente das construções finitas, onde há a elisão do $s e$; aqui há a inserção do $s e$; funcionando este como indeterminador, a fim de impedir que o sujeito seja referencialmente vinculado ao tópico. Citando Galves $(1987)^{15}$, o autor apresenta os seguintes exemplos:

(59) É impossível se achar lugar aqui.

(60) É impossível achar lugar aqui.

As sentenças infinitas acima apresentam uma diferença em suas construções - em (59), sentença do português brasileiro, o se aparece a fim de expressar a indeterminação; "toma-se como referência para esse sujeito nulo um antecedente na sentença ou no discurso" (NUNES, 1991, p. 49); já em (60), sentença do português europeu, "toma-se um antecedente na sentença ou tem-se uma interpretação indeterminada". (NUNES, 1991, p. 49). Essa diferença entre os dialetos torna-se ainda mais clara, segundo o autor, quando se utiliza a construção "é difícil de". A partir disso, o autor apresenta os exemplos de Galves (1987):

(61) O João é difícil de pagar.

a. É difícil de pagar o João.

b. É difícil de o João pagar.

(62) O João é difícil de se pagar.

\footnotetext{
${ }^{15}$ A obra à qual o autor se refere é $A$ sintaxe do português brasileiro.
} 
Em (61), a sentença configura-se como ambígua no português brasileiro, e gera duas proposições possíveis - a e b. Assim, para eliminar a ambiguidade na sentença, segundo o autor, o português brasileiro se utiliza do clítico se, gerando a proposição a.

\subsection{Menon (1992)}

A autora ressalta que há uma problemática em torno do se quando dos critérios da sua classificação. A depender do gramático, por exemplo, o se pode acumular mais ou menos funções. Segundo a autora, nas construções denominadas "passivas sintéticas" ou, ainda, "pronominais", o se pode ter as seguintes classificações: índice de indeterminação do sujeito ou partícula apassivadora; ou, ainda, pode ser considerado como sujeito do verbo a que refere (que está na voz ativa, nesse modelo de construção).

Nesse sentido, a autora defende que os falantes do português brasileiro não reconhecem mais o sentido passivo nas construções do tipo "passiva sintética"; o se funciona, nesses casos, como sendo sujeito das sentenças. Os exemplos abaixo ilustram isso:

(63) Vende-se casas.

(64) Vendem-se casas.

Em (63), segundo a maioria os gramáticos, há um erro de concordância verbal, pois o verbo [vender] não está concordando com o seu sujeito [casas]. Já em (64), há uma construção do que seria "aceitável" pela Gramática Tradicional. Trata-se, segundo eles, de uma construção na voz passiva sintética, cujo clítico se exerce a função de partícula apassivadora.

Sobre essa reinterpretação do clítico se para a posição de sujeito na sentença, a autora acrescenta que,

para que ocorra essa interpretação, o falante utiliza o método tradicional de identificação do sujeito, que consiste em perguntar "quem vende casas?", obtendo-se como resposta "se", equivalente a "alguém", "qualquer um", "um organismo". Acredito ser esta análise mais coerente que utilizar a glosa "casa são vendidas", que pode introduzir uma interpretação diferente, pois há casos em que a passiva não corresponde exatamente ao sentido da ativa. (MENON, 1992, p. 172).

Dentre os fatores que podem ter influenciado essa interpretação do clítico se como sujeito no português brasileiro, a autora salienta que a posposição do sujeito parece ser o fator 
mais proeminente. Para tanto, a autora faz uma revisão da literatura anterior que também considera tal fenômeno linguístico. Pontes $(1986)^{16}$, por exemplo, afirma que "a concordância em português varia conforme o registro e que na língua oral, até mesmo formal, é raro concordar o verbo com o $\mathrm{SN}^{17}$ posposto" e, também, que "a concordância verbal é talvez o critério mais falho na identificação do sujeito, pois existe a tendência para não concordar o verbo com o sujeito, tanto na fala como na escrita". (PONTES, 1986, apud Menon, 1992, p. 173).

A autora apresenta, também, algumas considerações de Bechara (1960), quando este analisa o verbo viver quanto à concordância nas sentenças a seguir:

(65) Vivam os campeões!

(66) Viva os campeões!

Segundo Bechara (1960), "a língua moderna revela acentuada tendência para deixar o verbo no singular, embora a gramática persista em ver aí erro de concordância”. (BECHARA, 1960, p. 95-96). Para que ocorresse tal transformação, isto é, da passagem do verbo no plural (como em 65) para o singular (como em 66), o autor elenca os seguintes fatores: o caráter interjectivo da frase, a influência das construções com a interjeição invariável salve e a posposição do sujeito (ou, como por ele denominado, de “anteposição do sujeito"):

a só anteposição do verbo ao sujeito é responsável por numerosas
infrações na concordância recomendada pela gramática. Assim,
apesar de ocorrer vitoriosa na linguagem coloquial, esta
concordância no singular deve ser rigorosamente evitada na
língua padrão. (BECHARA, 1960, apud Menon, 1992, p. 174).

Esses estudos apontam que, quando o sujeito vem posposto ao verbo, há uma forte tendência a não se realizar a concordância entre o verbo e o sujeito. Isso porque, segundo a autora, a concordância entre o verbo com o substantivo no plural, sobretudo nas passivas sintéticas, está relacionada à noção de "atração", ou nos termos de Said Ali $(2008)^{18}$, realizada por meio de "contágio":

\footnotetext{
${ }^{16}$ A obra à qual a autora se refere é Sujeito: da sintaxe ao discurso.

17 “SN" refere-se a Sintagma Nominal.

${ }^{18}$ A obra à qual a autora se refere é Dificuldades da Língua Portuguesa.
} 
diz-se corretamente: louva-se ao deus; adora-se aos idolos, mas: adoram-se os idolos; admira-se a Bernardes e a outros escriptores, mas: admiram-se os escriptores. A persistência da concordância com o objeto, onde não a estorva a presença de uma preposição, explica-se pelo contágio: é devida à influência de frases de verbo pronominal com sentido manifestamente reflexivo. (ALI, 2008, p. 112).

Outra questão relacionada à interpretação do se como sujeito, segundo a autora, seria o distanciamento do sujeito relativamente ao verbo nas construções formadas por locução verbal ${ }^{19}$. Além do distanciamento do verbo, "o fato de que ele é composto contribuem para considerar o se sujeito, pois o objeto direto é sentido como ligado à segunda forma verbal da locução e não ao auxiliar, forma conjugada”. (MENON, 1991, p. 176). A seguir, um exemplo do caso acima:

(67) Costuma-se distinguir os casos.

A sentença (67) mostra que há uma ocorrência do verbo auxiliar no singular seguido de um sujeito posposto no plural. Segundo a autora, o fato de não haver concordância entre o sintagma [os casos] e a forma verbal [costuma-se] dá-se, inicialmente pelo distanciamento entre ambos. Há, sobretudo, a interpretação de [os casos] como objeto direto do verbo [distinguir] não, necessitando, de concordância entre tais sintagmas, uma vez que não há a obrigatoriedade de concordar o objeto com o verbo.

Citando Hauy ${ }^{20}$ (1983), a autora ressalta que a questão da concordância está ligada à interpretação que o falante tem das passivas sintéticas:

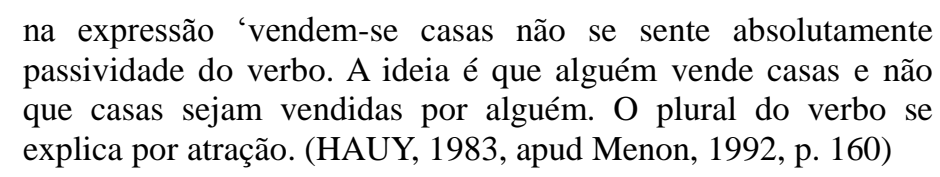

Nota-se, portanto, uma grande tendência a não se realizar concordância em sujeitos pospostos ao verbo; visto que a concordância, segundo a autora, ocorre por meio de "atração", ou seja, este irá concordar com o termo mais próximo a ele. No caso das passivas sintéticas,

\footnotetext{
${ }^{19}$ A autora, apresenta ainda discussões relativas a esse tipo de construção com dois verbos - se formam duas orações distintas ou se formam uma locução verbal. No entanto, não será objeto de análise neste trabalho.

${ }^{20}$ A obra à qual a autora se refere é Da necessidade de uma gramática-padrão da língua portuguesa.
} 
além da não-concordância entre o sujeito e o verbo, há uma reinterpretação na sentença: o se funciona como sujeito, e o sujeito como objeto direto.

\subsection{Bagno (2001)}

O autor afirma que o clítico se vem sofrendo significativas mudanças, tornando-se necessária a sua reanálise. Essa reanálise implica, sobretudo, na possibilidade de o se exercer a função de sujeito nas construções em que esse clítico é acompanhado de preposição e de infinitivo. Trata-se, segundo o autor, de um uso linguístico que não deve ser mais percebido como erro, pois a sua ocorrência está entre os falantes cultos e em textos de escrita monitorada, ou seja, já está integrada às regras da sintaxe do português brasileiro. Sobre essa inserção do se em contextos infinitos, afirma o autor que,

na sintaxe brasileira, aumenta progressivamente a tendência a não se deixar nenhum verbo sozinho, desacompanhado de seu sujeito, mesmo quando esse verbo é um infinitivo tradicionalmente classificado em impessoal. (...) O se (...) é um elemento que está se tornando essencial para as orações do português brasileiro. (BAGNO, 2001, p. 132, grifo do autor)

Assim, segundo Bagno (2001), o português brasileiro tem se tornado uma língua em que a presença do sujeito se torna cada vez mais exigida, "num processo que caminha (ao que tudo indica) rumo à obrigatoriedade dessa presença. Cada vez mais verbos aparecem acompanhados de seu sujeito, seja ele um nome ou um pronome”. (BAGNO, 2001, p. 132, grifo do autor). A seguir alguns um exemplo de construção com o clítico se entre uma preposição e um verbo no infinitivo apresentados pelo autor:

(68) Lugar bom de se morar.

A sentença acima, partindo dessa reanálise, é vista pelo falante do português brasileiro não como um enunciado passivo ("lugar bom de se morar"), mas como um enunciado ativo ("lugar bom de alguém/a gente morar"). Outros exemplos apresentados pelo autor evidenciam tal uso numa escrita dita "culta” na produção literária:

(69) Quando ficou forte era de se esperar que fugisse imediatamente mas demorou a ir em busca do próprio destino.

(70) Esqueci de dizer que era realmente de se espantar que para corpo quase murcho de Macabéa tão vasto fosse o seu sopro de vida quase ilimitado. 
(71) "Comédias para se ler na escola".

Nas sentenças (69), (70) há trechos coletados de obras de Clarice Lispector; e em (71) de Luís Fernando Veríssimo. Esses exemplos revelam que o uso do infinitivo com se também já se encontra em ambientes formais onde há monitoramento da escrita.

Outros exemplos apresentados por Bagno (2001) mostram a seguinte construção: "como era de se + infinitivo":

(72) Como era de se prever, um dia de Natal meio vazio, em que a programação de "Marte Ataca".

(73) Os bancos, como era de se esperar, chiaram contra qualquer hipótese de serem forçados a manter linhas ou comprar bônus do Brasil”.

(74) Como era de se esperar, as exigências quanto à qualificação são muito maiores do que as feitas para quem vai trabalhar no serviço de atendimento telefônico a clientes.

Segundo o autor, há uma frequente ocorrência desse tipo de construção, como nos exemplos (72), (73), (74), sobretudo, com o uso do verbo esperar, mostrando que esse tipo de construção já vem se tornando um sintagma que exerce a função de advérbio - uma locução adverbial -, tal como em (73) e (74).

A pesquisa de Bagno (2001) também revelou outros usos do se:

(75) O escândalo, hoje em dia, não está fácil de se conseguir, e o desbunde é muito insuficiente.

(76) Esta manobra, como é fácil de se imaginar, envolveu o conforto de famílias e profissionais de diversos níveis.

(77) Mas muitos vêem o boxe, particularmente, a categoria dos pesos pesados, como um meio fácil de se ganhar dinheiro.

(78) Era um apito bom de se ouvir, debaixo dos lençóis, e quanto mais distante se ouvia aquele trinado maior era o espaço protegido dos fantasmas e ladrões da noite.

(79) O certo é que futebol é bonito de se ver. E bom de se ler quando os textos envolvem o leitor com os ingredientes que cercam o futebol. 
(80) Resumindo, não há surpresas, mas o disco é bom de se ouvir.

(81) Ainda bem que está no passado. Passado triste, duro de se recordar.

Os exemplos (75), (76), (77), segundo autor, revelaram que a construção "fácil de se + infinitivo" também se mostrou em frequente uso, tal qual a construção "como era de se + infinitivo". Os demais exemplos (78), (79), (80) e (81) apresentam outros tipos de ocorrência, cujas construções com o se ocorrem sempre em contextos de preposição e de verbo no infinitivo. Portanto, os dados acima analisados por Bagno (2001) corrobora com o que o próprio título de sua pesquisa sugere: "o se cada vez mais sujeito".

\subsection{Duarte (2008)}

A autora analisa como se dá a realização do sujeito indeterminado em contextos infinitivos no português. À luz da Gramática Tradicional, a autora ressalta a definição de cada um dos infinitivos - impessoal e pessoal - a partir dos seguintes exemplos:

(82) Amar os homens é sempre uma alegria dolorosa.

(83) Há decisões fáceis de manter lembranças difíceis de afastar.

Em (82) e em (83), há sentenças com o infinitivo impessoal, o qual não apresenta flexão. Citando Bechara (1999) e Cunha \& Cintra (2001), a autora aponta que o verbo, nesse tipo de construção, "não faz referência a qualquer sujeito, exprime a ação de modo vago, à maneira do substantivo" (BECHARA, 1999, p. 244), e que esse verbo "não tem sujeito, porque não se refere a uma pessoa gramatical” (CUNHA; CINTRA, 2001, p. 484 - 486).

Partindo para a análise da estrutura dos argumentos selecionados pelos verbos acima, a autora ressalta que "cada infinitivo não flexionado seleciona um argumento externo e um interno e que o argumento externo, que realiza a função de sujeito gramatical dessas orações, está indeterminado". (DUARTE, 2009, p. 14). Essas características podem ser esquematizadas da seguinte forma:

(84) a. Øarb Amar os homens é sempre uma alegria dolorosa.

b. Há decisões i fáceis de Øarb manter Øi, lembranças k difíceis de Øarb afastar Øk. 
Nas sentenças a e b do exemplo (84) acima, apresentado pela autora, há a representação da arbitrariedade do verbo em relação à indeterminação do sujeito - em a, o verbo [amar]; e, em b, os verbos [manter] e [afastar].

Em relação ao infinitivo pessoal, o qual pode apresentar flexão, o sujeito indeterminado está relacionado à flexão verbal na terceira pessoa do plural. A seguir, um exemplo e a representação da estrutura argumental apresentados pela autora:

(86) a. Foi então que ouvi [baterem na porta.]

b. Foi então que ouvi [Øarb baterem na porta.]

Da mesma forma, o exemplo (86), mostra que em a, há um verbo flexionado na terceira pessoa do plural, manifestando-se em tal forma para indeterminar o sujeito. Essa forma arbitrária de indeterminação do sujeito (porque se refere a qualquer pessoa) é representada em b.

A Gramática Tradicional apresenta que essa diferença entre o infinitivo impessoal e o infinitivo pessoal está relacionada diretamente com a "inexistência de sujeito" e com a "existência de sujeito", respectivamente, e que somente na presença da desinência verbal, há um sujeito nulo de referência indeterminada. Segundo a autora, os gramáticos excluem a possibilidade do uso do clítico se mais infinitivo:

\begin{abstract}
a argumentação do gramático contra o uso de se junto do infinitivo é realmente interessante. Tanto ao tratar da função passiva quanto da impessoal do pronome se, nota-se que o autor confunde a função de sujeito oracional com a de sujeito do verbo no infinitivo. Por exemplo, em "Convém notar-se que ele errou", justifica a inutilidade do se com o argumento de que o sujeito de "convém" é "notar que ele errou". Ele não faz qualquer menção, porém, ao sujeito indeterminado de "notar", o verbo da oração subordinada (quem nota?). Os protestos do gramático são, sem dúvida, um indício de que o uso de se em variação com o sujeito nulo. (DUARTE, 2008, p. 15)
\end{abstract}

Em relação à escrita do português brasileiro, a autora afirma que o falante, "em vez de optar por um sujeito nulo (...), lança mão do clítico, seja como indeterminador, seja apassivador", (DUARTE, 2008, p. 24). Com base nisso, a autora apresenta estes dois exemplos: 
(87) Lugares para se divertir.

(88) Lugares para você se divertir.

Em (87), o se funciona como indeterminador, e em (88), o se funciona como apassivador.

Em relação ao contexto de indeterminação do sujeito, nota-se, que há uma tendência no português brasileiro para o preenchimento desse sujeito indeterminado na modalidade escrita, segundo a autora. Esse preenchimento, portanto, dá-se pelo clítico se, como em (89), contrariamente à utilização do sujeito nulo, como em (88):

(88) Lugares para comer bem.

(89) Lugares para se comer bem.

A autora ainda acrescenta que,

quanto ao uso de se na escrita, pode-se esperar que, por se tratar de uma forma de prestígio, preservada pela norma escrita padrão para a indeterminação em sentenças finitas, seu uso venha a aumentar nas sentenças infinitivas, satisfazendo a tendência de representar foneticamente (graficamente) o sujeito, fruto da mudança gramatical (...). Assim, o usuário vai superando a proibição de utilizar um se "sem utilidade". (DUARTE, 2008, p. 24, grifo meu)

Assim, o uso do clítico se nas construções infinitivas está relacionada à necessidade de representação do sujeito na sentença.

\section{Conclusões preliminares}

Neste capítulo, apresentamos a perspectiva linguística acerca do uso do se e do infinitivo a partir de quatro estudos. Cada análise elenca fatores que incidiram no emprego desse tipo de construção, como apresentado nesta seção. No quadro abaixo, propomos um esquema da análise quanto à interpretação do se referente às construções infinitivas: 


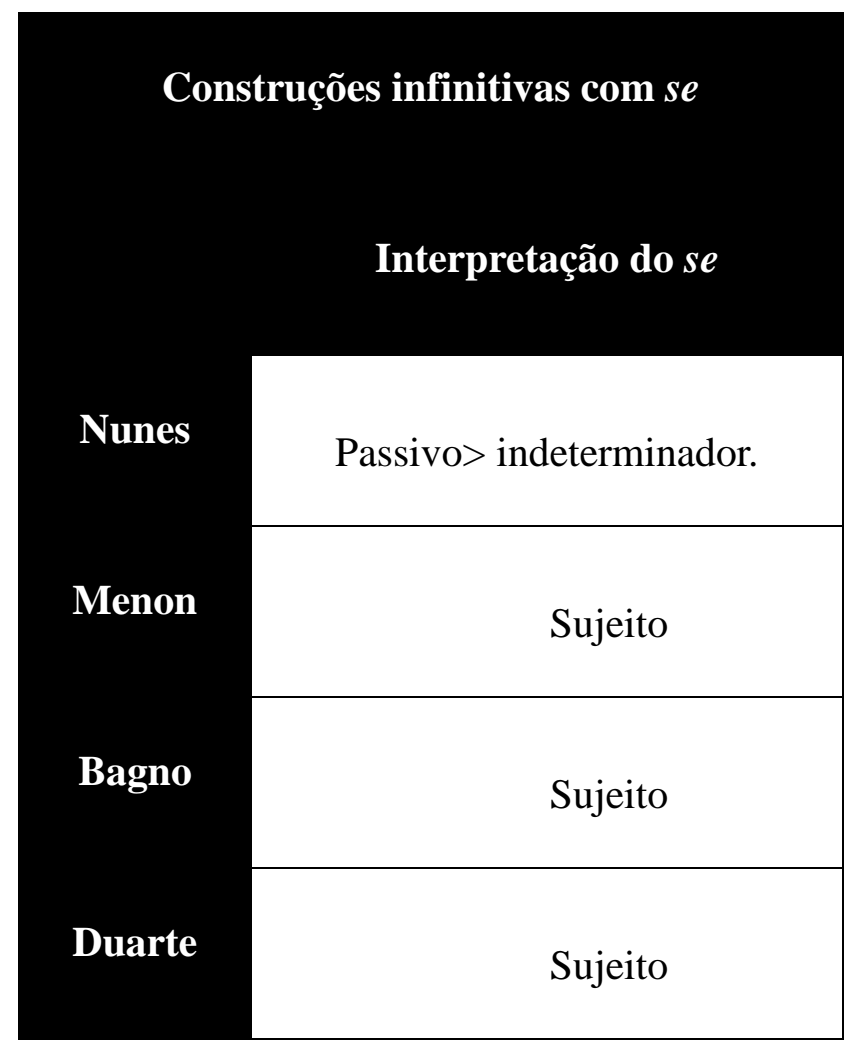

Todos os autores são unanimes quanto à classificação do se. Nunes (1991), por exemplo, traça um percurso diacrônico em torno do se para evidenciar a sua mudança de apassivador para indeterminador; bem como da sua inserção nas construções infinitivas no português brasileiro. $\mathrm{O}$ autor elenca alguns fatores que incidiram nessa mudança (como apresentado na seção 2.1); e da interpretação do se nesse tipo de construção - como um sujeito especial, a fim de expressar a sua indeterminação. Menon (1992), por outro lado, apresenta várias questões voltadas à reinterpretação desse clítico como sujeito nas passivas sintéticas e fatores que podem ter influenciado nesse emprego do se indeterminador - (veja na seção 2.2). Bagno (2001) também retoma tais questões e apresenta novos contextos sintáticos em que temos ocorre o se mais infinitivo, reafirmando a função do se como sujeito e como elemento essencial da sentença (veja na seção 2.3). Por fim, Duarte (2008) também analisa como se realiza o sujeito indeterminado nas construções infinitivas; enfatizando a necessidade de representação gráfica do sujeito nas sentenças do português brasileiro, que se faz por meio do se. 


\section{CAPÍTULO 3}

\section{Metodologia de Pesquisa}

\section{Introdução}

Este terceiro capítulo descreve a metodologia utilizada na pesquisa, dividido em duas seções: na primeira, descreve-se o objeto de análise e a questão de pesquisa e, na segunda, apresenta-se a metodologia de coleta de dados que definirá o corpus no qual se fundamenta a pesquisa.

\subsection{O objeto de análise e a questão da pesquisa}

O objeto de análise desta pesquisa se concentrará na apreciação de como se comporta o se nas construções com infinitivo em dois tipos de ambiente: formal e informal. Para responder a essa questão, a pesquisa irá a) descrever em que contextos ocorrem o se mais infinitivo, e b) analisar como o se pode ser interpretado em tais contextos. Na próxima seção, apresentaremos informações sobre os dados da pesquisa e como eles foram coletados.

\subsubsection{Descrição dos dados}

Os dados que servirão de base para a análise da pesquisa foram coletados na internet, em dois tipos de ambientes: formal e informal. $\mathrm{O}$ ambiente formal reuniu diversas fontes em sítios de notícias, como os jornais consagrados BBC Brasil, a Folha de S. Paulo e o G1 Notícias; e em outros sítios que veiculam notícias. Já no ambiente informal, a fonte de pesquisa se concentrou na rede social Facebook e em blogs de diversos gêneros (moda, culinária, esportes e etc.). Descrevemos, a seguir, as características de cada dessas amostras de língua e, também, a metodologia da coleta de dados utilizada.

\subsection{A amostra de língua escrita formal e informal: dados da internet}

Ambos os corpus de língua escrita formal e informal foram coletados na internet e os dados que serão analisados são procedentes de várias fontes. Quanto à língua escrita formal, optou-se por coletar os dados em sítios de notícias (jornais eletrônicos), e em sites que veiculam notícias em geral. A escolha desse tipo de dados foi impulsionada porque, nesses ambientes, espera-se a utilização do padrão culto da língua portuguesa, de acordo com as "regras gramaticais", cujas redações seguem uma escrita monitorada e são submetidas a 
revisões textuais. Constituem esse corpus de língua escrita formal 20 dados, os quais ocorrem o clítico se mais infinitivo.

Quanto à língua escrita informal, optou-se, primeiramente, pela coleta de dados na rede social Facebook. Pela insuficiência de dados, a coleta se estendeu a outro tipo de ambiente: blogs virtuais. A escolha desses dois tipos de ambiente se justifica porque, geralmente, caracterizam-se por possuírem menor rigidez às normas gramaticais, e não há tanto monitoramento da escrita. A pesquisa totalizou 30 dados.

A metodologia de coleta dos dados em ambos os casos foi bastante simples. Procedeu-se da seguinte forma: à medida que apareciam sentenças com a ocorrência do clítico se mais infinitivo em ambas as modalidades, os dados iam sendo coletados. É importante ressaltar que os dados aqui apresentados estarão em sua forma original, sem nenhuma alteração ortográfica ou gramatical. Não obstante, poderá ocorrer simplificações de modo a trazer o que realmente nos interessa para a pesquisa. Assim, se as sentenças coletadas tiverem contextos extensos, utilizaremos o símbolo “(...)” para marcar tal intervenção no texto original. O fenômeno analisado será marcado em itálico.

\subsubsection{Dados selecionados para a análise}

A coleta de dados culminou nos seguintes resultados: 20 dados de língua escrita formal e 30 dados de língua escrita informal, totalizando 50 dados. As tabelas a seguir mostram todas as ocorrências do se mais infinitivo, divididas pela transitividade verbal a qual o clítico se se combina, de acordo com os ambientes em que aparecem.

Tabela 1: Ocorrências do se mais infinitivo na língua escrita formal: 


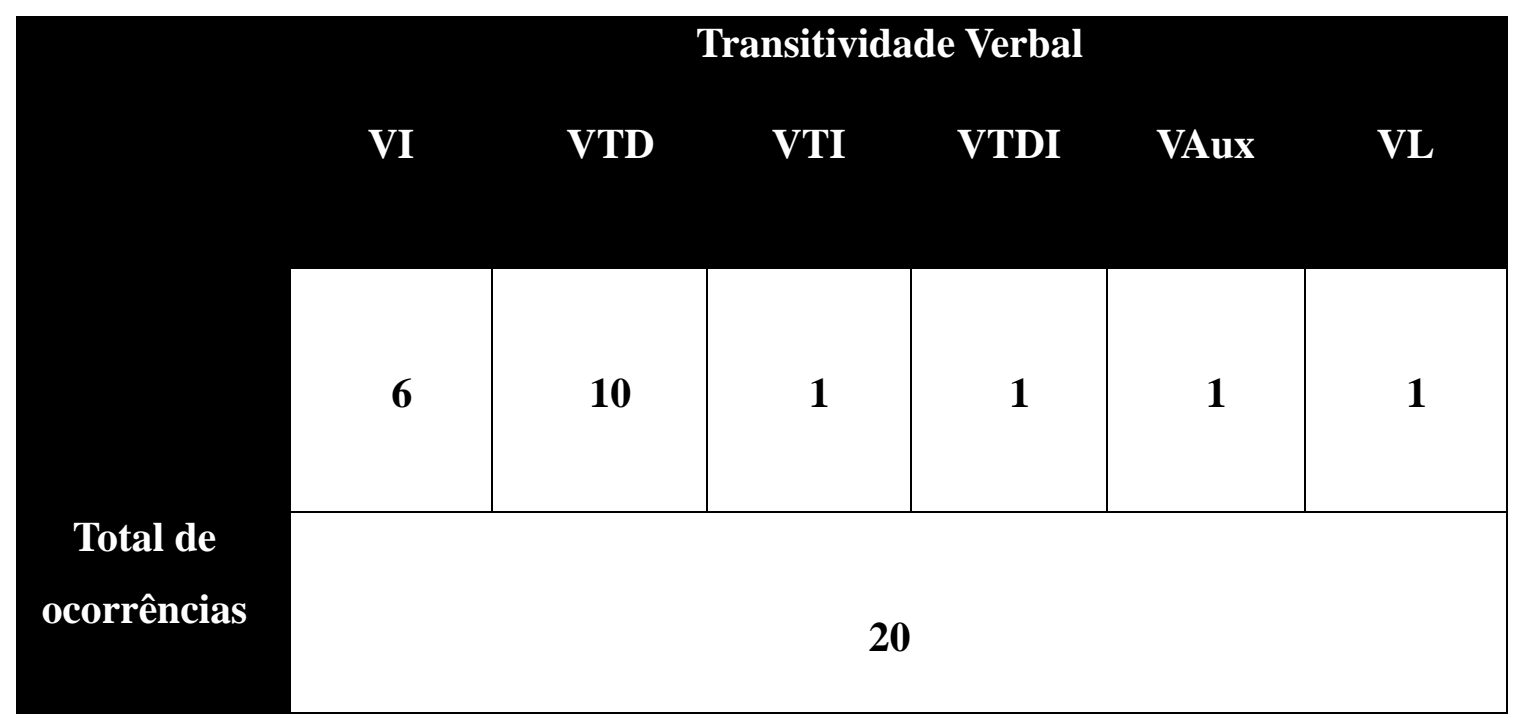

Fonte: elaboração da autora do trabalho.

Tabela 2: Ocorrências do se mais infinitivo na língua escrita informal:

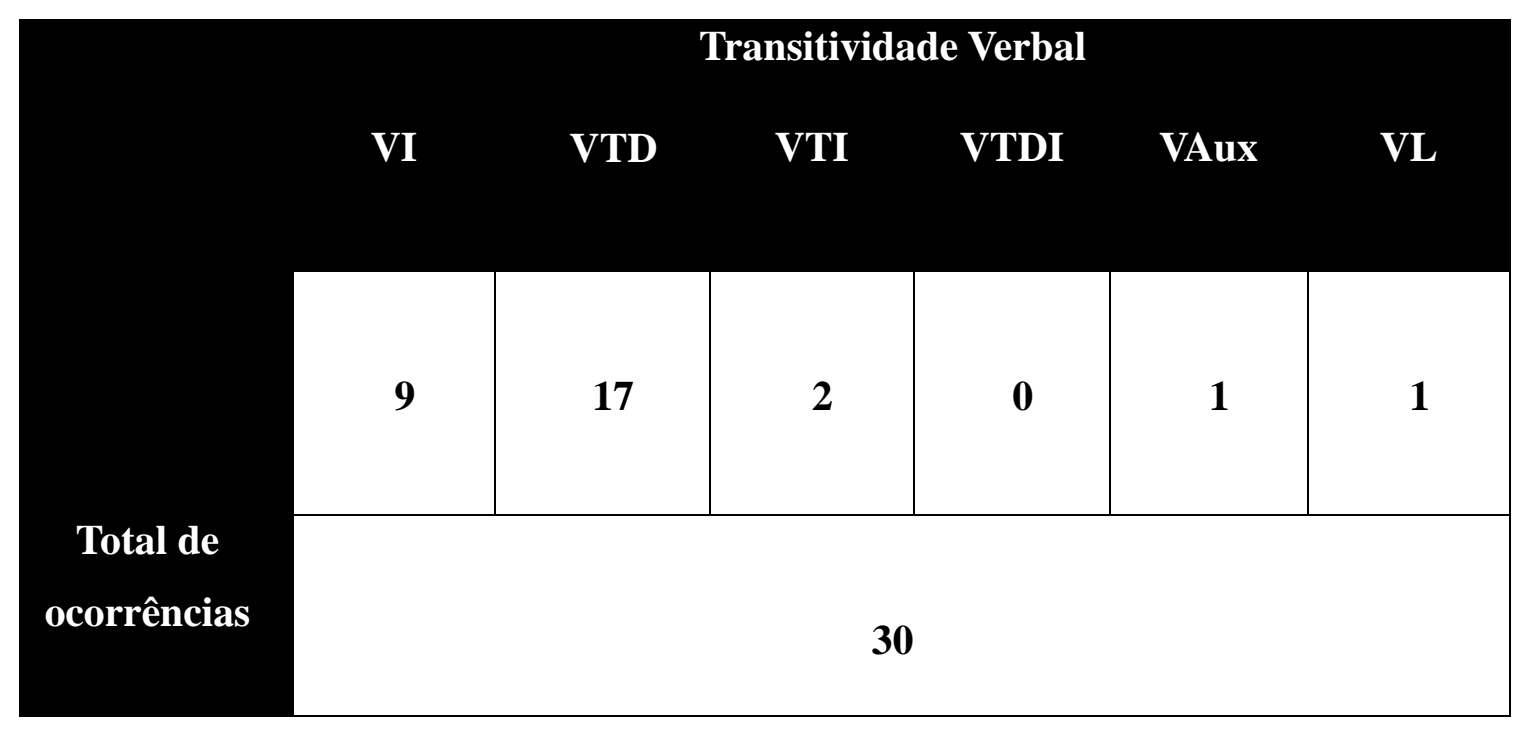

Fonte: elaboração da autora do trabalho.

\section{Conclusões preliminares}

Neste capítulo, foi apresentado o objeto de estudo desta pesquisa e a metodologia nele utilizada. O objeto de análise desta pesquisa é o uso do clítico se mais infinitivo, em dois contextos de língua escrita - formal e informal. A análise consistirá na apreciação desse 
tipo de construção descrevendo em que contextos ocorrem o se mais infinitivo, e analisando como o se pode ser interpretado em tais contextos, a partir das sentenças coletadas na internet. Os dados de língua escrita provêm de jornais eletrônicos e de outros sítios que veiculam notícias; bem como do Facebook e de blogs diversos. O corpus desta pesquisa compõe 50 sentenças, as quais serão analisadas no próximo capítulo. 


\section{CAPÍtULO 4}

\section{Análise dos dados}

\section{Introdução}

Neste quarto capítulo, analisaremos os dados coletados segundo a metodologia apresentada no capítulo anterior. A análise consistirá em dois momentos: primeiramente, descreveremos todas as sentenças coletadas, nas quais ocorrem o objeto de análise - uso do se mais infinitivo nos ambientes de língua escrita formal e informal ${ }^{21}$. Em seguida, analisaremos o clítico nas construções infinitivas em tais contextos, discutindo a sua função e as suas características de emprego.

\subsection{O uso do se mais infinitivo na amostra de língua escrita formal e informal}

Esta seção descreverá todos os dados coletados na internet, os quais estarão divididos em dois grupos: (a) dados extraídos de notícias e (b) dados extraídos do Facebook e de blogs, que se caracterizam em ambientes formal e informal, respectivamente:

\section{(a) Dados extraídos de notícias:}

(1) Oito perguntas sobre os riscos de se comer carne processada". (BBC Brasil, 29/10/15).

(2) De acordo com a revista "Time", o município Chongqing adotou a estratégia para alertar sobre os riscos de se andar olhando para baixo". (Folha de S. Paulo, 15/09/14)

(3). Como era de se esperar, roupas pretas dominam o dia do Metal no Rock in Rio. (O Globo, 19/09/16).

(4) A evolução das espécies de mamíferos com mais neurônios no córtex cerebral diminuiu a necessidade de se dormir tanto, e com isso, cresceram as oportunidades de alimentação levando a corpos maiores. (Uol Notícias, 23/09/15).

(5) Banco Central do Brasil reconhece importância de se conhecer melhor o cooperativismo. (Portal do Cooperativismo Financeiro, 21/09/16).

\footnotetext{
${ }^{21}$ Dados que fogem a essa descrição: exemplos (14), (21) e (23), coletados no ambiente informal. Esses dados não se enquadram no padrão: "NP/DP + para + se + verbo no infinitivo".
} 
(6) Ao mesmo tempo, o líder do RJ ressaltou que, apesar de se precisar de uma ideologia de Estado, esta não deve ser obrigatória, como ocorria na extinta União Soviética, cuja Constituição referendava o papel dirigente e reitor do Partido Comunista. (Uol Notícias, 18/11/16).

(7) A ênfase da blitz educativa será a orientação dos perigos de se transitar utilizando o telefone celular. (Agência Minas Gerais, 30/03/15)

(8) O diretor de jornalismo da TV Anhanguera, Álvaro Borges, diz que a campanha é uma forma de alertar a população para a importância de se doar sangue, principalmente neste período de férias, em que a demanda por bolsas de sangue é desproporcional ao número baixo de doações. (G1 Goiás Notícias, 14/07/16).

(9) Pagamento à vista, financiamento, consórcio, cooperativa habitacional, leilão: qual a melhor forma de se comprar um imóvel? (Uol Economia, 19/02/13).

(10) Conheça o risco silencioso de se morrer no banho. (Notícias R7, 05/10/16).

(11) Etanol será essencial para se diminuir a emissão de CO2 no Brasil. (Escola Politécnica da Universidade de São Paulo, 11/11/16)

(12) Grevílea é nova aposta para se fabricar móveis. (Gazeta do Povo, 09/01/06).

(13) Entenda conceitos básicos de física para se mandar um satélite para o espaço. (Agência $\mathrm{EBC}, 11 / 05 / 16)$.

(14) (...) Nadar é uma habilidade que geralmente se aprende na infância. Mas assim como pedalar, nunca é tarde para se aprender ${ }^{22}$ ou começar. (Folha de S. Paulo, 10/01/16).

(15) O vice do Sport declarou que é um risco desnecessário de se correr e citou o exemplo da partida entre Corinthains x Sport, que foi escalado um árbitro paulista Luiz Flávio de Oliveira e ele marcou um pênalti bastante polêmico de Rithely. (Folha de Pernambuco, 26/10/16).

(16) Estudo identifica as melhores empresas para se trabalhar no Rio. (O Globo, 30/07/16).

\footnotetext{
${ }^{22}$ É importante ressaltar que a transitividade verbal pode parecer estar sendo superficialmente alterada, porque em alguns casos, devido à própria construção em que aparecem alguns complementos verbais, estes podem ser omitidos, pois são facilmente recuperados pelo contexto. Nessa sentença, por exemplo, apesar de o objeto dos verbos "aprender" e "começar" não estarem graficamente representados na oração final, podemos, facilmente, recuperá-los na oração anterior - "aprender a nadar"; "começar a nadar".
} 
(17) Estudo recente divulgado pela empresa de pesquisa ValuePenguin aponta o Brasil como um dos países mais populares entre os estudantes norte-americanos. O País ocupa o $9^{\circ}$ lugar como o mais barato para se estudar. (Portal Brasil, 03/06/16).

(18) E o próximo domingo, dia 27, é o dia indicado para se estar com o presépio montado e a árvore enfeitada, porque é nesse dia que, pelo calendário litúrgico católico, começam as celebrações do Advento (época especial para o catolicismo). (Jornal da Cidade NET, 21/11/16).

(19) Além disso, apontou que o Uber está provocando o excesso de oferta de transporte individual, em vez de se estar ${ }^{23}$ fomentando o transporte público. (Câmara Notícias, 23/11/16).

(20) Antes de encarar a competição, o atleta deve se preparar. O preparador de corrida, Valdecarlos Santos, disse considerar a meia maratona uma das melhores competições para se praticar. (Portal do Governo de Mato Grosso, 12/10/16).

Nas sentenças acima, coletadas de notícias de jornais eletrônicos e de demais sítios que veiculam notícias, há a repetição da seguinte construção: preposição + clítico $s e$ + verbo no infinitivo (não flexionado). Apesar da alternância entre as preposições de e para, nota-se a predominância do uso da preposição "de" - totalizando 11 ocorrências.

\section{(b) Dados extraídos do Facebook e de blogs:}

(1) Ótimo local para se comprar artesanato.

(2) Os lugares mais baratos e mais caros para se comer pelo mundo.

(3) Não existem teorias ou fórmulas secretas para se escrever bem.

(4) Preguiça de sair? Analu mostra cinco exercícios para se fazer em casa.

(5) Além de estar na frente de uma praça, que é sempre um bom lugar para se jogar o game.

(6) A Igreja da Sé é um ótimo lugar para se encontrar Pokémons do tipo Fada, como Clefairy, Clefable, Jiggypuff, Wigglytuff e Mr. Mime.

\footnotetext{
${ }^{23}$ Por uma questão metodológica, optamos por classificar o verbo "estar" como verbo de ligação, apesar de ele não apresentar, nessa sentença, caraterísticas próprias de um verbo de ligação; como o fato de se combinar com adjetivos para formar o predicado nominal. Exemplo: Meu irmão é trabalhador.
} 
(7) Os 15 lugares mais inacreditáveis para se nadar no mundo.

(8) Músicas para se ouvir em viagens.

(9) Qual a melhor gordura para se cozinhar?

(10) Então hanaji é escrito como はなぢ, de acordo com ち: o hiragana básico para se transcrever 血.

(11) Por isso fica até complexo às vezes abranger o que é mandatório seguir uma dieta hipercalórica para se poder ganhar massa muscular.

(12) Algumas razões para se aprender outros idiomas.

(13) Copenhague é considerada uma das melhores cidades para se andar de bicicleta no mundo, com uma estrutura praticamente ideal.

(14) (...) Para se viver bem é preciso preparar-se para a morte.

(15) (...) visto que é essa a necessidade derradeira para se morrer bem e santamente, pedindo o perdão por todos os seus pecados, confessando-os e recebendo a última unção nessa vida.

(16) Conheça modelos de tênis ideais para se usar no verão.

(17) Estes são os melhores programas VoIP para se telefonar gratuitamente ou com baixo custo via internet.

(18) Skype - um dos melhores programas para se fazer chamadas VoIP para outros computadores, telefones fixos ou celulares.

(19) 8 principais sites para se reclamar de uma empresa na internet.

(20) 365 lugares para se conhecer em São Paulo.

(21) Hoje, para se testemunhar fidelidade a Jesus e aos Seus ensinamentos, os testemunhos são de ordem moral; pedem renúncia e abnegação sem limites em favor do próximo. (...)

(22) Excelente lugar para se buscar a espiritualidade. 
(23) A vida é muito curta para se estar ${ }^{24}$ sempre no mesmo lugar.

(24) Razões para se pedir uma cesárea.

(25) Para solucionar a questão, é importante se ter em mente que a Lei de Licitações trouxe apenas três possibilidades para se finalizar um procedimento licitatório.

(26) 10 dos mais lindos lugares para se visitar na Espanha.

(27) Inteligência não é possuir todas as ferramentas. Inteligência é possuir poucas (para andar leve), e saber onde encontrar as que não se têm, na eventualidade de se precisar delas.

(28) Um dos melhores lugares para se passear nesta zona é o parque Chacabuco.

(29) Um macaquinho que chega a $10 \mathrm{~cm}$ de altura, está na classe dos exótico mais populares para se ter como pet.

(30) Há algo essencial para se saber ${ }^{25}$ antes de fazer a reserva: os quartos velhos são velhos mesmo, com tapete manchado, televisão CRT com 10 anos de uso, em estado bem ruim.

Nas sentenças acima, também há a repetição da seguinte construção: preposição + clítico se + verbo no infinitivo (não flexionado). No entanto, nesse tipo de construção, há a predominância da preposição "para”, totalizando 30 ocorrências.

A partir dessa primeira análise, já é possível descrever o primeiro padrão encontrado nas duas amostras da pesquisa. Abaixo, propomos um esquema que mostra a construção sintática nos ambientes formal e informal, respectivamente, em relação às construções infinitivas com $s e$ :

\begin{tabular}{|c|c|}
\hline Preposição & Contexto Sintático \\
\hline de & adjetivo + de $+s e+$ verbo no infinitivo \\
\hline para & $\mathrm{NP} / \mathrm{DP}+$ para $+s e+$ verbo no infinitivo \\
\hline
\end{tabular}

\footnotetext{
${ }^{24}$ Nessa sentença, optamos, também, por classificar o verbo "estar" como verbo de ligação, apesar de ele não ter características prototípicas dos verbos de ligação.

${ }^{25}$ Quanto à regência do verbo "saber”, utilizaremos a classificação VTD.
} 
Nota-se que no ambiente informal, a preposição de foi predominantemente utilizada, tendo como contexto sintático padrão a seguinte estrutura: adjetivo $+\mathrm{de}+s e+$ verbo no infinitivo. No ambiente formal, a preposição para teve predominância do seu emprego, associada ao contexto sintático: NP/DP + para + se + verbo no infinitivo.

Nas sentenças que têm a preposição para em sua estrutura, notamos que parece que há uma lacuna a ser preenchida ou por um objeto direto; ou por um adjunto adverbial; e que o antecedente dessa lacuna está sempre na oração anterior. Observemos os exemplos abaixo:

(4) Preguiça de sair? Analu mostra cinco exercícios para se fazer em casa.

(20) 10 dos mais lindos lugares para se visitar na Espanha.

(6) A Igreja da Sé é um ótimo lugar para se encontrar Pokémons do tipo Fada, como Clefairy, Clefable, Jiggypuff, Wigglytuff e Mr. Mime.

(18) Skype - um dos melhores programas para se fazer chamadas VoIP para outros computadores, telefones fixos ou celulares.

Nos exemplos (4) e (20), notamos que a complementação da ideia expressa pelos verbos das orações finais (fazer e visitar) pode ser recuperada a partir da oração anterior; e nas orações (6) e (18), a relação de adjunção dos verbos da segunda oração está expressa, também, na oração anterior. Observemos a reescrita dessas sentenças abaixo:

a. (...) para se fazer [exercícios] em casa.

b. (...) para se visitar [lugares mais lindos] na Espanha.

c. (...) para se encontrar Pokémons (...) [na Igreja da Sé].

d. (...) para se fazer chamadas VoIP (...) [com o Skype].

Nas duas primeiras reescrituras, observamos a recuperação do objeto direto “exercícios", em (a); e "lugares mais lindos", em (b). Nas duas últimas reescrituras, notamos a recuperação da adjunção, pelo adjunto "na Igreja da Sé”, em (c), expressando uma ideia de lugar; e pelo adjunto "com o Skype" em (d), traduzindo uma ideia de instrumento.

Por outro lado, nas sentenças que têm a preposição de em sua estrutura; não identificamos o mesmo padrão, uma vez que essa preposição, na amostra coletada, aparece 
ou como parte de uma locução ou para introduzir um complemento. Vejamos nos exemplos a seguir:

(3) Como era de se esperar, roupas pretas dominam o dia do Metal no Rock in Rio. (O Globo, 19/09/16).

(4) A evolução das espécies de mamíferos com mais neurônios no córtex cerebral diminuiu a necessidade de se dormir tanto, e com isso, cresceram as oportunidades de alimentação - levando a corpos maiores. (Uol Notícias, 23/09/15).

No exemplo (3), era de se esperar forma uma locução, traduzindo uma "fórmula fixa”, como já apontado por Bagno (2001). Já no exemplo (4), a preposição de antecede o complemento nominal "de se dormir tanto", complementando a palavra "necessidade".

Quanto à transitividade verbal, nas 20 sentenças coletadas no ambiente formal, identificamos, inicialmente, todos os tipos de verbos: intransitivo (6), transitivo direto (10), transitivo indireto (1), transitivo direto e indireto (1), auxiliar (1) e de ligação (1). No ambiente informal, também observamos todos os tipos de verbos: intransitivo (9), transitivo direto (17), transitivo indireto (2), auxiliar (1) e de ligação (1), com exceção de verbos transitivos diretos e indiretos.

Essa extensão da transitividade verbal nos mostra a possibilidade de qualquer tipo de verbo se combinar com o clítico se, como já apontado por Nunes (1991):

\footnotetext{
uma vez que o português passou a admitir construções em que um pronome referencial nulo da posição de sujeito é indeterminado pelo clítico se, era de se esperar que qualquer verbo - não apenas os transitivos - que pudesse ter um pronome referencial nulo da posição de sujeito (possuindo o traço [+HUM] pudesse fazer parte de uma construção com se indeterminador. (NUNES, 1991, 43-45).
}

Apesar de ser possível a construção infinitiva com se em todos os contextos de transitividade verbal, notamos um contraste entre os complementos diretos e indiretos na nossa amostra. Como visto na análise acima, a recuperação ou do objeto direto, ou do adjunto adverbial só ocorreu nas construções com objeto direto. Quanto às sentenças de transitividade indireta, não temos, ainda, uma explicação para o fato de não serem possíveis as construções analisadas com objeto indireto do verbo no infinitivo, mas gostaríamos de deixar registrado os dados para um estudo posterior: 
(6) Ao mesmo tempo, o líder do RJ ressaltou que, apesar de se precisar de uma ideologia de Estado, esta não deve ser obrigatória, como ocorria na extinta União Soviética, cuja Constituição referendava o papel dirigente e reitor do Partido Comunista. (Uol Notícias, 18/11/16).

(19) 8 principais sites para se reclamar de uma empresa na internet.

(27) Inteligência não é possuir todas as ferramentas. Inteligência é possuir poucas (para andar leve), e saber onde encontrar as que não se têm, na eventualidade de se precisar delas.

Quanto aos verbos intransitivos, identificamos um certo estranhamento em relação aos inacusativos pela a) ausência de objeto direto; e b) da não possibilidade de reconstrução do sintagma nominal em adjunto adverbial. Observemos o exemplo a seguir:

(15). (...) visto que é essa a necessidade derradeira para se morrer bem e santamente, pedindo o perdão por todos os seus pecados, confessando-os e recebendo a última unção nessa vida.

Nesse exemplo, não é possível transformar o elemento DP/NP em adjunto adverbial. Vejamos nas reescrituras abaixo:

a. (...) visto que é essa a necessidade derradeira para se morrer [pela necessidade derradeira].

b. (...) visto que é essa a necessidade derradeira para se morrer para se morrer [da necessidade derradeira].

c. (...) visto que é essa a necessidade derradeira para se morrer [com a necessidade derradeira].

Esse estranhamento dá-se por não ser possível que o sintagma [a necessidade derradeira] seja reinterpretado na oração final - nem como objeto direto, nem como adjunto adverbial.

Já os verbos inergativos, notamos a possiblidade de o NP/DP ocupar a posição de adjunto adverbial na oração final. Observemos os exemplos abaixo. 
(13) Copenhague é considerada uma das melhores cidades para se andar de bicicleta no mundo, com uma estrutura praticamente ideal.

(17) Estes são os melhores programas VoIP para se telefonar gratuitamente ou com baixo custo via internet.

(28) Um dos melhores lugares para se passear nesta zona é o parque Chacabuco.

Ou seja, é possível que o termo nominal [os melhores programas VoIP] seja reinterpretado como adjunto adverbial. Vejamos nas sentenças a abaixo.

a. (...) para se andar de bicicleta [em Copenhague].

b. (...) para se telefonar gratuitamente ou com baixo custo via internet [com os melhores programas VoIP].

c. (...) para se passear [em um dos melhores lugares].

A partir dessas análises, já é possível responder às questões de pesquisa deste trabalho: a) o se mais infinitivo, na nossa amostra, ocorre em dois contextos sintáticos preposicionados. O primeiro contexto sintático segue o seguinte padrão: adjetivo $+\mathrm{de}+s e$ + verbo no infinitivo, predominantemente utilizado no ambiente de língua escrita formal. $\mathrm{O}$ segundo contexto sintático segue o padrão: NP/DP + para + se + verbo no infinitivo; predominantemente utilizado no ambiente de língua escrita informal; e b) o se é interpretado como indeterminador (Nunes, 1991), exercendo a função de sujeito; em conformidade com os autores Menon (1992), Bagno (2001), e Duarte (2008).

Em relação aos tipos de ambiente em que a pesquisa foi realizada, nos questionamos: será que os dados coletados, realmente, caracterizam-se em formal e informal? Pode ser que não. Mas, é importante ressaltar que o fato de esse tipo de construção ter sido encontrado em diversos contextos de língua escrita formal - em cujos textos, além de seguirem o padrão culto da língua portuguesa, seguem um monitoramento da escrita e, geralmente, passam por acuradas revisões - nos mostra que o uso do infinitivo com se já pode estar integrado à sintaxe do português brasileiro.

\section{Conclusões preliminares}

Neste capítulo, descrevemos e analisamos as 50 sentenças com a manifestação do se mais infinitivo. A análise evidenciou dois fatos: a) o se mais infinitivo, na nossa amostra, 
ocorre em dois contextos sintáticos preposicionados. O primeiro contexto sintático segue o seguinte padrão: adjetivo $+\mathrm{de}+s e+$ verbo no infinitivo, predominantemente utilizado no ambiente de língua escrita formal. O segundo contexto sintático segue o padrão: NP/DP + para $+s e+$ verbo no infinitivo; predominantemente utilizado no ambiente de língua escrita informal; e b) o se é interpretado como indeterminador em tais contextos, exercendo a função de sujeito. O ambiente de coleta de dados evidenciou que o infinitivo com se já é encontrado no português brasileiro, e esse tipo de construção não é usado somente na escrita formal informal, como, também, é recorrente na escrita formal. 


\section{CONSIDERAÇÕES FINAIS}

Esta pesquisa voltou-se ao estudo do clítico se mais infinitivo. Partimos das Gramáticas Tradicionais - Gramática Normativa da Língua Portuguesa, Nova Gramática do Português Contemporâneo e Moderna Gramática do Português apresentam - analisando o que tais obras abordam sobre o emprego do infinitivo no português; e o uso do se como indeterminador e como apassivador. Sobre o infinitivo, consideramos que, apesar de os autores apresentarem inúmeras regras quanto ao emprego do infinitivo, tais regras não são fixas; além de os gramáticos não deixarem claro o emprego distintivo do infinitivo. Em relação ao uso do se, os gramáticos classificam-no de acordo com os verbos com os quais ele se combina; atribuindo às suas sentenças a voz passiva ou a indeterminação do sujeito, dando ênfase, estritamente, à transitividade verbal ${ }^{26}$.

A forma de abordagem de tais conteúdos não foi tão relevante para a nossa pesquisa, uma vez que o nosso objetivo era descrever em que contextos ocorrem o se mais infinitivo; e entender como esse clítico pode ser interpretado em tais contextos; para além das regras que os gramáticos prescrevem.

Em seguida, analisamos a perspectiva linguística sobre o nosso tema de pesquisa. Para tanto, utilizamos quatro trabalhos: Nunes (1991), Menon (1992), Bagno (2001), e Duarte (2008), que serviram de base para analisar os nossos dados. Tais trabalhos contribuíram para a) assumirmos que o se é indeterminador; e b) a função do se é a de sujeito; em contextos infinitivos.

Com base nesses pressupostos teóricos, damos início à nossa coleta de dados. Os dados foram coletados na internet, em dois tipos de ambientes: formal e informal, os quais reuniram diversas fontes, como sítios de notícias, Facebook e blogs. Ao todo, coletamos 50 dados, sendo 20 dados em língua escrita formal e 30 dados em língua escrita informal. A seguir, descrevemos os padrões encontrados nesses dados:

\footnotetext{
${ }^{26}$ Com exceção do Bechara, que já fala da possibilidade de passagem do emprego da passiva à indeterminação. Veja na seção 1.3.2.
} 
a. Todas as sentenças apareceram em contextos sintáticos preposicionados, obedecendo à ordem: preposição (de ou para) + se + verbo no infinitivo (nãoflexionado).

b. Nos dados de amostra de língua formal, notamos que houve uma preferência pelo uso da preposição de - de um total de 20 sentenças, houve 12 ocorrências - no seguinte contexto sintático: adjetivo $+\mathrm{de}+s e+$ verbo no infinitivo.

c. Nos dados de amostra de língua informal, houve uma preferência pelo uso da preposição para - de um total de 30 sentenças, houve 29 ocorrências -, manifestando-se no seguinte contexto sintático: $\mathrm{NP} / \mathrm{DP}+$ para $+s e+$ verbo no infinitivo

d. Nas sentenças de língua informal, que têm a preposição para em sua estrutura, notamos que havia uma lacuna a ser preenchida ou por um objeto direto; ou por um adjunto adverbial, e que o antecedente dessa lacuna estava sempre na oração anterior. Esse padrão, no entanto, não foi encontrado nas construções de transitividade indireta.

e. Quanto aos verbos intransitivos, há um certo estranhamento nas sentenças inacusativas pela impossibilidade de um termo nominal ser reinterpretado na oração final - nem como objeto direto (pela própria natureza da transitividade), nem como adjunto adverbial. Já nas sentenças inergativas, é possível fazer essa reinterpretação em adjunto adverbial.

f. A amostra de dados de língua formal revelou que mesmo em contextos de extremo monitoramento da escrita, há a ocorrência do se mais infinitivo, que é considerado por muitos como "erro". No entanto, esse uso pode mostrar que essa categoria já pode estar integrada à sintaxe.

g. Assumimos que o se, no tipo de construção analisada, é interpretado como indeterminador, conforme Nunes (1991). Esse clítico, também, exerce a função de sujeito, em conformidade com os autores Menon (1992), Bagno (2001), e Duarte (2008). Tal posicionamento justifica-se pelo fato de o se acumular características próprias de sujeito. 
Essa foi a contribuição do nosso trabalho - a descoberta de tais padrões que não são abordados nos trabalhos anteriores. Duas questões ficaram em aberto: por que nas sentenças de transitividade indireta não são possíveis as construções analisadas com objeto indireto do verbo no infinitivo? Será que os resultados obtidos caracterizam, de fato, nas escritas formal e informal? É possível que seja uma característica da nossa amostra de dados, porém, só a ampliação dos números de dados possa vir a dar respostas consistentes a essas perguntas. Essa parte pesquisa fica como agenda de trabalho posterior. 


\section{REFERÊNCIAS BIBLIOGRÁFICAS}

SAID ALI, Manuel. O pronome se. In: Dificuldades da língua portuguesa. 7.ed. Rio: Acadêmica, p. 101-119, 2008.

BAGNO, Marcos. O se cada vez mais sujeito. In: Português Brasileiro: um convite à pesquisa. 2 ed. São Paulo: Parábola, 2001.

BECHARA, Evanildo. Moderna Gramática Portuguesa. 37 ed. São Paulo: Nova Fronteira, 2009.

CUNHA, Celso; CINTRA, Lindley. Gramática do Português Contemporâneo. 6 ed. Rio de Janeiro: Lexikon, 2013.

DUARTE. Maria Eugênia Lamoglia. O sujeito de referência indeterminadora em sentenças infinitivas. Revista do GEL, S. J. do Rio Preto, v. 5, n. 1, p. 9-30, 2008. Disponível em: < https://revistadogel.gel.org.br/rg/article/view/131/111> Acesso em: 23 de agosto de 2016.

ROCHA LIMA. Gramática Normativa da Língua Portuguesa. 49 ed. Rio de Janeiro: José Olympio, 1992.

MENON. Odete Pereira da Silva. Considerações em torno do se: “Se passivo?". Revista Letras. Curitiba, vol. 42, p. 171-193, n. 4, 1992-1993. Disponível em: <http://revistas.ufpr.br/letras/article/download/19124/12424> Acesso em: 23 de agosto de 2016.

NUNES, Jairo M. Se Apassivador e Se Indeterminador: O Percurso Diacrônico no Português Brasileiro. Caderno de Estudos Linguísticos. Campinas, v. 20, p. 33-58, 1991. Disponível em: <http://revistas.iel.unicamp.br/index.php/cel/article/view/2907/4111>. Acesso em: 23 de agosto de 2016. 